\title{
Disease Response Assessment Time
}

National Cancer Institute

\section{Source}

National Cancer Institute. Disease Response Assessment Time. NCI Thesaurus. Code C162175.

The time at which a disease response assessment is completed. 